\title{
A Class against Capital: Class and Collective Bargaining in Guangdong
}

Tim Pringle, SOAS University of London

\begin{abstract}
This paper argues that a class against capital emerged in Guangdong province between 2007 and 2014. I base my arguments on data drawn from significant strikes in the province and the processes of collective bargaining that partially resolved them. I observe that the formation of a working class against capital in Guangdong, made up primarily of migrant workers, has at least partially overcome fragmentary pressures it continues to face. I argue that it is the self-activity of workers themselves that is chiefly responsible for the significant improvement in wages and, to a lesser extent, working conditions that unfolded during this period. While collective bargaining remains mostly - but not exclusively - outside institutional norms, workers' agency pushed the practical application of forms of collective bargaining on to both the political and labour relations agenda in Guangdong and beyond. Continued pressure from below will keep it there.
\end{abstract}

Keywords: Guangdong, class struggle, labour movement, collective bargaining, working class formation, class against capital

Tim Pringle is a Senior Lecturer in Labour, Social Movements and Development at SOAS with special reference to China. Tim entered academia at the tender age of 45 when he embarked on a PhD program at the University of Warwick while simultaneously working as a co-investigator on a major research project examining trade union reform in Russia, China and Vietnam. He has published two books: Trade Unions in China: the challenge of labour unrest (Routledge, 2011) and The Challenge of Transition: trade unions in Russia, China and Vietnam (Palgrave, 2011) with Professor Simon Clarke.

\section{Correspondence address:}

Senior Lecturer, School of Oriental and African Studies, London/UK. Thornhaugh Street, Russell Square, London WC1H 0XG; E-mail: tp21@soas.ac.uk 


\section{Introduction}

The cautious emergence of collective bargaining has been the most intriguing aspect of China's evolving labour relations framework. While class struggle has been the impetus for this experiment there is little doubt that the Communist Party of China (CPC) still controls the rules of the game as recent detentions of activists in Guangdong province have demonstrated all too clearly. The Party's attempts to ameliorate labour unrest arising from the antagonistic interests of capital and labour has been especially marked in Guangdong where mainstream notions of collective consultation (jiti xieshang) have been challenged by recognisable processes of collective bargaining (jiti tanpan). This paper will examine the appearance of nascent forms of collective bargaining, which, it should not be forgotten, are unfurling in the context of Party-led trade unionism and authoritarian rule. I base the paper on the Marxist conceptualisation of class formation, namely a class against capital. I argue that the growth of interest-based strikes in the period 2007 to 2014 in Guangdong suggests that the class fragmentation that characterised China's period of high economic growth has been undermined by the emergence of a class against capital.

First however, I will clarify my preference for the formulation of class against capital over the more traditional 'class in itself' that is frequently juxtaposed against a more class conscious and confrontational 'class for itself'. In this I am guided by the work in particular of Andrew and his analysis of 'Karl Marx and his Classifiers' (Andrew, 1983, p.577). Andrew argues, with wonderful clarity, that Marx 'never referred to classes in themselves or distinguished a class in itself from a class for itself' (ibid.). In doing so Andrew draws directly on Thompson's famous representation of class as a form of conflictive behaviour generated by shared experiences in the production processes. This relational approach is contrasted to Cohen's structural class in itself- class for itself dichotomy. For Cohen, a person's class 'is established by nothing but his objective place in the network of ownership 
relations' (Cohen, 1980, p.76 cited in Andrew, 1983,p.578). Thus the concept of a class in itself separates class from class conflict - an approach analogous with the administrative categorization of migrant workers in China as peasant workers (nong mingong). This descriptor hardly captures the dynamic class struggles that have both forced state and capital to collective bargaining tables in Guangdong province. Following Andrew's citation from Marx's Poverty of Philosophy, my approach focuses on the combination of economic conditions and class struggles.

Economic conditions at first transformed the mass of the people of the country into workers. The combination of capital has created for this mass a common situation, common interests. This mass is thus already a class against capital, but not yet for itself. In the struggle...this mass becomes united, and constitutes a class for itself. (Marx and Engels, 1976, p.211 cited in Andrew ibid., p.280)

Three decades of economic reform have provided a 'combination of capital' distinguished in Guangdong by massive inflows of foreign investment and the plurality - or 'network' to use Marx's word - of property relations. In the Chinese-language literature this is often described as the 'complication' (fuza hua) of enterprise ownership. As the translations of Anita Chan (1998), China Labour Bulletin (1998) and others have demonstrated, the millions of young women and men who left the land to work in Guangdong's export boom were never not against capital and the concomitant injustices of rapid industrialisation that has been the hallmark of East Asian development (see for example, Koo's account of working class formation in Korea). But it was not until the early years of the present century that the material conditions emerged - at least in Guangdong - for the largely individualised grievances of migrant workers 'under assault' (Chan, ibid.) from globalisation to cohere into 
a class against capital. Whether the forces of labour will overcome renewed onslaughts of fragmentation and repression from capital and state to constitute a class for itself that can be the driving force pushing further progress towards centralised collective bargaining remains a moot point. However, my focus is on the substitution of the formulation 'class in itself' with 'class against capital'.

Although this paper engages with the issue of class consciousness by implication, it is not explicit. I consider the relationship between individual consciousness and collective action as highly complex, especially in a post socialist authoritarian state where 'the phrasing of demands is more likely a tactical judgement than a spontaneous expression of "consciousness"” (Clarke, 2014, p.760). As such, by pinning the recent progress in collective bargaining to levels of consciousness, there is a danger of idealising what is essentially an instrument of class compromise into a transformative - even revolutionary - device that will attain its full potential once the class consciousness of workers has matured beyond a narrow focus on the pay packet. This in turn generates room for misinterpretations: on the one hand, under-acknowledging the significant gains made by strikes; and on the other hand, attaching too much political significance to the institutional response of such gains namely - for the purposes of this paper - evolving forms of collective bargaining.

Rather, I use primary research on sanitation workers in Guangzhou alongside an analysis of three major class struggles across Guangdong to demonstrate the emergence of a class against capital drawn primarily from the ranks of migrant workers. One result of this process has been a concomitant struggle for participatory collective bargaining - a classic instrument of class compromise that I employ as an approximate bell-weather to evaluate the forces of labour in the province. By participatory collective bargaining I mean scenarios in which workers are engaged - directly or indirectly - in negotiations with capitalists, state officials and sometimes both. By indirectly I mean at the very least aware of such 
negotiations; and by directly I mean as strikers, workers representatives or both. In either case, these negotiations are in stark contrast to the tradition of collective consultation that is characterised by the disengagement of workers as a social class from the entire process.

The remainder of this paper is organised as follows: Section two will review key literature on class formation in China in the context of my adoption of the class against capital approach. Section three will discuss key strikes in relation to the literature covered in the previous section and provides a context for my case study of strikes by sanitation workers in Guangzhou. I conclude with a summary discussion that will make some cautious observations on the future development of collective bargaining in Guangdong.

My paper draws on interviews conducted during fieldwork in Guangdong and Hong Kong in June-July 2013 spread over two 12-day research trips; Hong Kong in July-August and October 2014 spread over two 10-day trips; and Beijing in December 2014. This fieldwork included interviews with 20 sanitation workers - most of these with the supervised assistance of a labour NGO with over a decade of experience in conducting such interviews two auto parts factory workers, 12 labour NGO staff as well as numerous conversations with labour relations academics, union officials and activists in Shenzhen, Panyu, Guangzhou, Hong Kong and Beijing. The primary data on the Yantian port strike in 2007 is drawn from the author's participation as a co-investigator on an ESRC project entitled Post-Socialist Trade Unions, Low Pay and Decent Work: Russia, China and Vietnam (Grant Reference RES-155-25-0071). Interviewees' names are not stated in accordance with the conditions under which most of the interviews were agreed. My primary research is supported by secondary sources drawn from relevant academic journals, books and newspaper articles in Chinese and English as well as material elicited from labour NGO websites and reports. The fieldwork in Guangdong was funded by faculty research grants from SOAS, University of 
London where the author is employed as a Senior Lecturer in Labour, Social Movements and Development.

\section{Class formation}

At the national level, the potential for working class solidarity against the forces of capital is fragmented from above via categorisations defined by the state or capital: peasant worker (nongmin gong), urban worker (zhigong), part-time worker (linshi gong), dispatch worker (paiqian gong) student worker (xuesheng gong) as well as temporarily (in theory) laid off state-enterprise workers (xiagang gongren) (Pringle, 2011, pp.11-55). These administrative and contract-based categories are fractured further by gendered state-constructed ideal type narratives of economic migration via labels such as dagongzhe (migrant worker) and dagongmei (Fu, D., 2009, p.527). Fragmentation from below in the form of home-town associations rarely organised around class interests can also serve the interests of capital and weaken the potential for solidarity. On the other hand, Chan has shown vividly how such organisations can quickly transform into conduits for class solidarity in the course of struggles (Chan, C., 2009, p.60). Indeed, it is precisely in this conflictive behaviour that lines of fragmentation - be they imposed from above or formed from below - are reconfigured and joined up along class lines as migrant workers 'find common interest against other men whose interests are different from (and opposed to) theirs' (Thompson, 1963, p.9). Indeed, I see this phenomenon as an illustration in support of Andrew's critique of structuralist interpretations of Marx's ideas on class formation in which there is a tendency to reduce class to a sociological category.

Nevertheless, Pun and Lu track a process of 'unfinished proletarianization' to capture the second generation of migrant workers and the constraints on organising. They argue that 
because the restrictions of the hukou regime effectively tie one's right to permanent residence to place of birth, workers are prevented from establishing their own 'working class community' (Pun and Lu, 2010, p.498). Consequent incomplete class formation is further compounded by the other side of the hukou regime that retains peasant workers' access to land. Pun and $\mathrm{Lu}$ argue that this differentiates the current period of industrialisation in Guangdong from the English industrial revolution: '[U]nlike the English working class, the Chinese working class faced no coercion effectively forcing on them a process of industrialisation' (Ibid. p.505). Drawing on ethnographic work carried out between 2005 and 2008, they highlight the 'huge gulf' between the 'life expectation of becoming urban workercitizens and their actual daily experiences which are characteristic of the dormitory labour regime and which involve serious exclusion from city life' (Ibid. p.495-6). However, as with hometown associations, the dormitory regime imposed by capital is transformed by workers' conflictive behaviour. Chan and Pun (2009, p.291) argue that both hukou's separation of production and reproduction and the generalised rural-urban chasm in China are recombined in a dormitory regime that generates a specific form of proletarianisation. Charting the organisational development of two strikes in 2004 and 2007 respectively, they find that the 'workers dormitory and urban communities, no matter how temporary, provide the potential to facilitate labour mobilization and collective consciousness building' (Ibid. p.303). They conclude that the consequent struggles are part of an historic and long-drawn out formation of a 'class for itself' (Ibid. p.303).

While Friedman rarely uses these terms, his analysis of the separation of the impact of the 'specific process of proletarianisation of Chinese migrant workers' (Ibid. p.291) is likewise informed by spatial themes and their links to capital flows. But he is generally much less sanguine over the issue of class formation in general and the likelihood of a working class against capital in particular in the context of migration. Migrant workers, argues 
Friedman (2012) 'do not refer to themselves as "workers," nor do they think of themselves as part of the "working class." Furthermore, he argues that the spatial separation of production from reproduction means that 'migrants who are lucky enough to have employer-supported social insurance - a small minority - are paying into a system that they will never benefit from. If pensions are not portable, why would a migrant demand a better one?' (Ibid.). We should not be surprised to learn that this argument was formulated prior to the shoe workers strikes over pensions that exploded in 2014 ! Thus the temporal realities of migrant workers temporary presence in the cities dictates a rational focus on wages that is particularly relevant to young workers years off pensionable age. Friedman is more optimistic when he turns his attention to the recent increase in capital investment and urbanisation of the interior where the 'terrain of particularity' on which class struggles occur offers a more conducive set of conditions for the 'politicization of worker unrest' and 'more enduring forms of organization' (Ibid). Lower barriers to permanent residence in the second-tier cities of the interior offer the opportunity for migrant workers to 'demand all the things one needs for a decent life housing, health care, education, and some protection against the risks of unemployment and old age' (Ibid.). Friedman seems to juxtapose an underestimation of the potential for struggles beyond wages in the 'huge eastern megalopolises' with a sophisticated optimism regarding the emergence of what Marx would refer to as class for itself in the interior.

\section{The Rising Forces of Labour}

Our starting point for this section is the now landmark strike in a Honda-owned auto parts factory in Foshan, Guangdong. Viewed from a 'class in itself' perspective, the strike was not, in the main, conducted by what either Honda management or the Chinese legal system would term 'workers', even less, workers that form part of a class against capital. Although initially led by two full time employees (Lyddon et al, 2015, p.140), the main block of strikers were 
so-called 'student workers' or interns from vocational colleges elsewhere in China that have become an important source of labour power over the last decade (Cole and Chan, 2015). The fact that most of the strikers were not regular employees rendered them outside the formal protection of the Labour Contract Law and local regulations that implement it - or perhaps not. As students, they were not members of the plant's trade union and were working in conditions inferior to regular workers (Chan and Hui, 2012, p.659). Their labour power was disciplined by teachers whose leverage over them lay with the authority to withhold educational certificates on completion of the period of 'internship' thereby shutting off opportunities for more secure employment at the factory and likely elsewhere. Smith and Chan (2015: 311) argue that student workers form part of a strategy by both capital and local level governments to fragment actual and potential class solidarities.

However, the direct and collective relationship of these workers with the means of production, in an auto parts supply chain that awarded them considerable 'structural power' (Wright, 2000, p.962; Lyddon et al, 2015, p.148), provided the material conditions for student and regular workers to organise a 17-day strike. The unrest concluded with the strikers' demands being largely met: a significant pay rise and the election of a re-organised trade union committee at the plant - although the higher level Guangzhou Federation of Trade Unions insisted that the incumbent chair be allowed another term to improve his performance.

We can see here the strength of Andrew's rejection of the class in itself formulation. Regardless of their administrative or legal status, the strikers found common interest 'against other men' (Thompson, 1963, p.9) and combine around demands for effective trade union representation and improved wages. The 'other men' here are Honda's owners and managers and their state partners who, alarmed at the power of the strike, broke ranks and agreed to facilitate collective bargaining between capital and elected workers' representatives. Viewed 
solely as a class 'constituted by the economic structure...rather than constituting itself in partisan combination and combat' (Andrew, 1983, p.584), the role of the student interns and their significant contribution to China's labour movement would be logically downplayed, if not written out of the history books altogether - as I am sure the CPC will be happy to do. On the other hand, when viewed as a key - if not necessarily permanent - component of a class against capital, we are able to analyse the outcome of the strike for what it really represented: a negotiated class compromise premised on the withdrawal of the labour power by a combination of migrant workers, student workers and local workers that overcame imposed fragmentation to act as members of a working class despite legal and bureaucratic constraints on such action. The strike and the sustained solidarity it generated was an expression of working class power that kick-started both copycat strikes as well as annual pay bargaining at the plant that has since spread to other auto sector plants in Guangzhou (Interview No.1; Chen Weiguang, 2013). Workers at the Honda plant struck briefly again in 2013 expressing discontent with the outcome of a collective wage bargaining round (Schmitt, 2013; Interview No.1). Some workers and observers have interpreted the more recent strike as the outcome of management attempts to weaken the influence of the elected trade union committee at the plant (Interview No.1; Interview No.8). While this is certainly a setback, it may also be regarded as a symbol of management's wariness of effective trade union activity and workers' capacity to organise it.

Honda's student workers overcame constraints and barged their way into a working class against capital via their own actions. Over a much longer period, the imposed concept of peasant worker (nongmin gong) has started to dissipate in the face of strikes by 'peasant workers' subject to its discriminatory power and divisive narrative (Pringle, 2013,p.112). Hukou has nevertheless served as a valuable weapon of labour control for both state and capital (Lee, 2007, p.207) underpinning a generalised narrative of victimhood (Chan, A. 
1998, p.3). Migrant workers in Guangdong for example were disregarded by the ACFTU due to their assigned status of peasant worker as opposed to urban worker or zhigong who constituted the union's traditional membership. In the vacuum, many migrants turned to labour NGOs (LNGO) for assistance with work related grievances ranging from unpaid overtime to longer campaigns claiming compensation for industrial injury and disease. In recent years, strikes by so-called 'peasant workers' have driven a coach and horses through the victim scenario, none more so than the actions by dock workers at Yantian International Container Terminals (YICT).

YICT is a port terminal in Guangdong province that has expanded to form a crucial node in China's export-orientated economic growth (South China Morning Post, 11 April 1996: 2). Most YICT workers are migrants who have taken advantage of the relaxation of hukou restrictions resulting from labour shortages to establish long term residence in the area. In 2007, YICT crane operators took strike action in pursuit of higher wages linked to the port's phenomenal growth and a recalculation of the lunch break as working hours. The strikers also demanded a trade union branch operated by elected representatives whose wages would be paid, according to the demands of the workers, directly out of their own wages (case study reports, 2007). The structural power of these strikers derived from their position at a key logistical node of global production and supply chains. The strike produced an almost immediate backlog of ships waiting to be loaded with exports destined for Western markets (South China Morning Post, 9 April 2007: 1). This in turn focussed the attention of the politically powerful Shenzhen Federation of Trade Unions (SFTU) with senior officials rushing to the scene at two o'clock in the morning. The SFTU facilitated talks between elected representatives of the strikers and YICT management in a bargaining process that won almost all of the workers' demands with the important exception of the workers' wish to fund their own trade union representatives directly. The SFTU refused to negotiate this 
demand on the grounds that it would constitute a violation of the Trade Union Law that stipulates union dues are deducted by the employer and transferred directly to the higher union.

The strike settlement led to the establishment of a union branch based on check-off contributions administered by management; a system for electing union representatives and a substantial pay rise including a recalculation of the lunch hour. As with the Honda strike, annual pay bargaining was established at the port and has produced above inflation-rate pay rises all carefully documented by the SFTU (Interview No.10). Significantly, a second strike occurred at the port in 2013 that involved most of the workers in the 2007 strike. The cause of the more recent strike was dissatisfaction with the outcome of collective wage negotiations (Interview No.10). We see here what I have described elsewhere as an 'appropriation of associational power'. By this I mean that the city-level SFTU was forced to respond to the need for a functioning primary trade union in order to head off militancy that showed signs of developing towards the struggles of a class for itself across various ports in Guangdong (Interview No.10) via demands for better representation and collective bargaining outcomes. However, in this formulation I part company with Andrew. In his view, a 'class in itself-class for itself' dichotomy is a 'Leninist constriction of Marxist politics and a doctrinal limitation to empirical application of class analysis' (Andrew, 1983, p.584). However, my focus here remains on the emergence of a class against capital that is developing the capacity to constrain it via collective bargaining as was the case at YICT (Pringle and Quan, forthcoming).

Dongguan's low-end manufacturing sector has been a key player in the Pearl River Delta's 'workshop of the world' story. The city is notorious for long working hours, poor health and safety and wage-levels requiring extensive overtime for migrant workers to move beyond the most basic standard of living (Financial Times, 9 February 2009: 4). During the 
late nineties, multinational brands that had taken advantage of these conditions responded to consumer-led pressure from the Global North for improved working conditions by introducing various versions of corporate social responsibility and accompanying codes of conduct in their supply chains. In China, these initiatives have failed to produce a sustainable impact on workers' pay and conditions (Yu and Pun, 2011, p.70; Chang and Wong 2005, p.154). On the other hand, the emergence of labour shortages combined with a knowledge of labour rights accumulated over three generations of rural-urban migration have provided the conditions for the development of short factory-based bursts of often intense labour unrest. These have included strikes defended by picket lines and the raising of interest-based demands - often considerably beyond the level stipulated by the minimum wage - settled via negotiation with the employer and varying degrees of state and official trade union interventions (Pringle, 2013, pp.114-132; Liu, 2010, pp.30-52; China Labour Bulletin, 2014, p.38). As the first generation of migrant workers have acquired seniority via up to 15 years of hard slog at the sharp end of global supply chains, demands have increasingly included adequate social security provisions based on the stipulations of the Social Security Law that came into force in 2010 or the regulations that preceded it. These latter strikes have been led by older workers whose connection with any form of agricultural work was severed in their late teens even though some family members still have access to land as a result of hukoudetermined land use rights. Nevertheless, the demands of these workers are working class demands premised on a consistent relationship with the means of production that they neither own nor control and which constitute a means of survival and reproduction. But this is much more than a structural economic relationship.

Evidence of how far migrant workers have travelled towards 'proletarianisation' was provided by a dramatic strike at the Taiwanese-owned Yue Yuen (YY) strike during April 2014 (see Chan and Hui; and Schmalz et al in this issue). A massive 40,000 workers took part 
(China Daily, 30 October 2014: 5) in this extraordinary strike. The initial demand was for YY to pay full social insurance premiums and public housing fund payments as well as make up for the deficits resulting from underpayments dating back to 2005 (China Labour Bulletin 2014a). According to posts on social media outlets such as weibo, workers' slogans included militant condemnations of the employer's 'illegal behaviour' (weibo.com/u.1266932233 account no longer accessible). An extended interview with a veteran YY worker conducted by an experienced activist and posted on the Worker View Point blog (Gong Ping She, 2014) illustrated the deep associations with long-term waged employment.

About 70 per cent of the workers have been here [i.e. at YY] for more than five years and between 10 to 15 per cent for ten - starting work at the factory as 18 - and 19-year olds. There are levels of trust between senior workers that creates a sense of unity. Some even have [grown up] children working here (Gong Ping She ibid.).

The two-week strike was eventually broken by a heavy police intervention that saw riot police escorting workers back to YY assembly lines. This repressive behaviour was only partly offset by pay rise of RMB 230 per month with strikers' opinions diversifying over the issue of social insurance arrears (ibid.). Nevertheless, the sheer scale of the strike and the fact that it was able to stop production by force of numbers has put enormous pressure on the Guangdong Federation of Trade Unions (GDFTU). In post-strike follow up meetings, GDFTU Chairperson Huang Yebin organised meetings in Dongguan at which he urged local township- and enterprise-level trade unions in the city to pilot democratic methods in building up responsive trade union branches (GDFTU News Centre, 15 July 2014). While this strike was by no means a clear victory for the workers, its scale and character were the outcome of working class formation generating demands that go beyond individualised rights 
and represent collectivised class interests that go beyond the pay packet and look towards retirement and social security. Labour activists with contacts inside the factory have predicted there will be further labour unrest as the main issues of low pay and social insurance arrears have not been solved (Interview No. 6). While collective bargaining has not emerged at YY or in the shoe sector in general, there is evidence that this is the direction the GDFTU wishes to proceed at least in this direction - albeit slowly and on its own terms. Moreover, the strike suggests that contrary to Friedman's expectations, the spatial separation of production and reproduction has not excluded demands that go beyond a focus on wages and is further evidence of a class against capital forged in conflictive behaviour. Both the strike at YY and the second strike at YICT included social reproduction related demands over the pensions in the case of the former and housing provident scheme payments at YICT. There is also evidence from strike maps compiled by CLB and other organisations that more and more strikes include similar demands (CLB 2015).

This section has presented a brief tour of strikes in Guangdong across three key industries: auto, logistical and shoe respectively. I have hardly scratched the surface and make no claim on the representative credentials of these strikes. But I have picked examples that have either produced ongoing collective bargaining via elected representatives or demonstrated a clear need for it that has been at least partially acknowledged by the Party-led trade union. The key point is that the strikes demonstrate the emergence of a 'class against capital' rooted in class struggles. In the period under consideration, this has in turn generated a decisive shift in the balance of class forces in Guangdong that has seen both capital and state having to take part in forms of collective bargaining with workers' representatives who they would not have given the time of day to just a few years previously. This paper does not set out to examine the presence or otherwise of levels of class consciousness usually deemed a key factor in a 'class for itself' scenario. However, I and others have argued elsewhere that 
the copycat nature of strikes between 2008 and 2013 in Guangdong illustrate the first stirrings of a coherent class-based labour movement (Pringle, 2013, p.195; China Labour Bulletin, 2014, p.5) although this view is certainly contested (Friedman, 2013, p.303).

The next section examines the struggles of a section of Guangzhou's working class in a comparatively weaker bargaining position - sanitation workers (huanwei gong). In doing so, I will test my arguments that a class against capital has emerged in Guangdong between 2007 and 2014; and that future development of the collective bargaining that has formed part of response will be likely theoretically grounded on the premise that it is an instrument of class compromise i.e. not revolution through which workers with common interests reach agreement with 'other men whose interests are different from (and opposed to) theirs' (Thompson, 1963, p.9).

\section{Sanitation Workers in Guangzhou}

Usually in at least their late forties and working alone for most of a day's shift, sanitation workers hardly fit the social media savvy, networked, consumer-orientated, well-dressed and modern image of '[T]he rising power of Chinese workers' as represented by the famous cover of the Economist in 2010 (Economist 29 August - 6 September, 2010). On the other hand, although subject to outsourcing, these were not informal workers in the ILO definition of the term. All but one had contracts that included deductions for all five aspects of labour insurance and, since 2012, contributions to a housing provident fund. By making use of the structural power they possessed in refusing to clean streets and the consequent implications for public health, Guangzhou's sanitation workers have won significant concessions. Neither the state nor capital in Guangdong deployed their almost certain capacity to organise sufficient numbers of scab labour to break the sanitation workers strikes. They opted to bargain directly with the representatives of a class against capital. 
I selected this group of highly exploited workers as a case study precisely because their material conditions seem to support the arguments of unfinished proletarianisation and the separation of production from reproduction that I reject as insurmountable barriers to the formation of a class against capital rooted in class struggles resolved - at least partially - via collective bargaining. Subjected to segregation from above by outsourcing, and often migrant, older - my sample of 20 interviewees had an average age of 48 - unskilled, female and isolated by the labour process, this group would present enormous challenges to any organiser pretty much anywhere.

Sanitation workers were originally employed directly by the government across Guangzhou's districts. Between 2004 and 2006, the sector was deregulated and the work opened up to tender to hundreds of companies. The outsourcing has created a chain of financial transactions that involves private landlords, government agencies, neighbourhood and street management committees and private cleaning companies (libcom.org, 2014). In this system, government agencies collect fees off landlords and private residents that are then used to pay the private companies that have won street cleaning contracts. From the sanitation workers' perspective, the potential for late payment or worse is clear but more important to them is the frequent change in employer - sometimes every year - with each new company involved seeking to lower labour costs by reducing staff and increasing workloads. Some simply change the terms of contracts even - or perhaps especially - of workers who have been cleaning the same streets for up to ten years (Interview No.5). This system of outsourcing and frequent changes of contracts has been a key factor underlying recent strikes by sanitation workers:

Yes, I took part in the strikes in 2013. There was a sit-in at Culture Park as a result of non-payment of welfare privileges we were entitled to. The strikes [started] back in 
2007 resulting from a change in cleaning company that reduced our welfare entitlements. Back then we - hundreds of workers - went on strike, marched down the main road with big banners and shouted slogans. We blocked the road as a result. Then we marched to the government office demanding that they intervene [with the cleaning company]. There is a change in company every two or three years and this sparks a strike (Interview No.4).

The GZFTU responded to the fragmentation of sanitation workforce across tens of companies by setting up a sector-level Sanitation Workers Union. Its Luogang district branch apparently concluded a collective agreement with six companies in 2009 (Yangcheng Wanbao, 21, July, 2009). However, the initiative certainly did not prevent the increases in workload. As one interviewee from Yuexiu district explained:

Take the rubbish bins on the main roads. Originally four people would be involved in the process of removing, washing and returning the bins. This was reduced to three, then two and now one person...I moved from work in a factory because I was getting too old for the pace of work. But it's becoming just as hard on this job (Interview No.3).

Despite the long hours of working alone in allocated streets, the label of 'peasant worker' that sits well with the nonconflictual structural categorisation of a class in itself and misattributed to Marx (Andrew, 1983, p.584) - was indirectly rejected during the interviews - especially by workers who had taken part in the strikes. This was sometimes quite explicit. One interviewee pointed out that as [W]ages are the source of income for all workers and 
therefore we sanitation workers are workers too. This 'peasant worker' business is government speak and I don't buy it ('zhengfu de hua') (Interview No.2).

Most of the workers had little confidence in the trade union - and in four cases, no knowledge of it at all. Despite this many of the workers did take part in union elections although they were usually dismissive of the process. In most cases, views on the union were expressed in terms of it not being able to represent 'we sanitation workers' against the interests of capital that were overwhelmingly deemed as separate to their collective interests. Indeed, I would argue that in the context of the absence of freedom of association and protection of the right to strike, lack of faith in the ACFTU combined with participation in strikes is a clear - if indirect - indication of allegiance to a collective identity as a working class that is against capital well aware that demands of wages and pensions were against the interests of 'other men' (Thompson, 1963,.p.9) who preferred to fragment their interests across city districts.

Interviewees criticised the divisive wage system that resulted in workers being paid different amounts for the same work depending on the sub-district they worked in. In the Yuexiu district of Guangzhou this system was known as the ' $1+18$ ' model (Interview No.6). Further, a common - if minority view - was that sanitation work was a public service that should not be privatised as it essentially had been. As one street cleaner explained:

This outsourcing to [private] employers and changing employers every year is not in anyone's interests except them. I think that the entire system should be brought back to how it was before and we should be directly employed by the government. This [street cleaning] is a public service (Interview No.7). 
One of the most interesting challenges that emerged from my adoption of Andrew's rejection of class in itself lies in the conundrum that some of my data appeared to support Andrew's observation that 'Cohen's class in itself denotes a definitive structure underlying experience and behaviour' (Andrew, 1983, p.582). Most of the quotes above seem to suggest a structural understanding of the position of sanitation workers in society but the recollections of strikes and struggle was fading. At times these memories seemed to concur with the idea that '[V]isible struggles are appearances or phenomena to be explained by the noumenal structure of class in itself' (ibid. p.582) and the solidarity they represented was fleeting. Although most of the sanitation workers interviewed expressed the view that their interests were essentially collective and certainly not the same as those of capital, the 'conception of a class against capital [that] suggests an empirical understanding of manifest opposition, struggle of conflict as definitive' (ibid. p.582) was at times qualified, to a greater or lesser degree, by time. This was in contrast to data from my research on the other strikes in Guangdong discussed in this paper.

But then came the explosion of sanitation worker unrest in the autumn of 2014. I was fortunate enough to be in a position to interview activists involved in organising this strike very soon after its successful conclusion and the data confirmed my inclinations towards Andrew's class against capital or rather his interpretation of Marx's approach. The 2014 strike took place in University Town district and was again sparked by the annual change of the employer (Interview No.9). Sanitation workers began electing their own representatives in the last week of August and launched strike action on the 26 August (Interview No.9). Following protracted negotiations with the employers, the strikes won a RMB 3,000 per year's employment as compensation for contract termination against the outgoing company's original offer of 1,000 RMB. There was no suggestion of a structural confinement in the ideas expressed in interviews with sanitation workers leaders by LNGOs. On the contrary, the 
views of Wu Naiyang and $\mathrm{Yu}$ Wucang bristle with 'empirical understanding of manifest opposition' (ibid. 582) as they call on the state to support their struggle against capital. As sanitation worker and representative explained to an LNGO supporting the strike:

The local government is the beneficiary of our hard work and it is in their interest to stand with us when the employer changes. We love the expression $\mathrm{Yu}$ [Wucang] proposed: "Steel-forged workers and ever-changing companies." This is our community, and we are here to stay (China Labour Bulletin, 2014b - emphasis added).

Moreover, in the wake of the University Town strike, the incoming cleaning company largely failed in its attempts to divide local and migrant workers from Hunan by announcing a policy of only re-hiring local workers. Another sanitation worker and representative responded that 'there are no locals or non-locals, the striking sanitation workers at University Town are a big family, and we stand together' (China Labour Bulletin, 2014c). This does not look like unfinished proletarianisation. For China's foremost labour lawyer and collective bargaining expert, these words capture 'the courage, resilience and bargaining skills of the unofficial layer of workers representatives that has emerged in Guangdong' (Interview No.11). These are the women and men at the forefront of Guangdong's class against capital.

\section{Conclusion}

The introductory words of the Rules of the International Workingmen's Association are clear enough: 'The emancipation of the working class must be conquered by the working classes themselves' (International Working Men's Association, 1867). In this task, their primary target is capital itself and a logical premise for its completion is the identification of capital as 
having interests antagonistic to their own. The capitalist state, as a relation of capital, is not on their side. A nominal workers' state with its particular narrative of struggle and domination is perhaps a trickier barrier than more familiar social formations of capital. Indeed the ideological barriers to the formation of a class against capital in this context should not be underestimated. Consider the impact of being reminded, as perhaps some of the currently detained labour activists such as Zeng Feiyang, He Xiaobo, Zhu Xiaomei, Meng Han, Peng Jiayong and Deng Xiaoming are being reminded right now as I sit safely in my office far away, that the preamble of the Chinese Constitution is unambiguous on the issue of class power. Its preamble states that China is a 'people's democratic dictatorship led by the working class'. No need, they may be firmly told, to build up and train fully accountable workers' representatives in the arts of collective bargaining. The 'other men whose interests are different from (and opposed to)' yours are all subject to the people's democratic dictatorship and led by the working class. So back off - or else.

My paper here has attempted to provide evidence that this is not the case. By deploying a Marxist approach to class formation conceptualised, as Andrew reminds us, as a class against capital, I have tried to relocate the working class back where it belongs in emerging processes of collective bargaining - centre stage. My argument is temporally bound between 2007 and 2014 and spatially confined to Guangdong, a period in a dramatic increase in class struggle in various sectors across the province constrained some of the worst excesses of rapid capital accumulation. Given the current levels of repression of LNGOs and activists, the further consolidation of Guangdong's class against capital may be held up by continued state interventions; or even reversed by industrial relocation (Butollo, 2014). And of course, attempts by capital to block improvements in labour's internal position will increase tension and challenge the state's capacity to mediate stable capital-labour relations - generating pressure on the ACFTU to up its game. Or the process may re-emerge on different terrains as 
Friedman (2012) suggests. Or all of this may happen. In the meantime, strikes continue to dominate industrial relations in Guangdong and beyond and strikes require the self-activity of workers and their supporters. This activity is not only inseparable from institutionalised and authentic collective bargaining. It is the key to the future of the labour movement itself.

\section{Interviews}

Interview No.1: Auto worker, Foshan/China, 24 July 2013.

Interview No.2: Sanitation worker, Guangzhou, 10 August 2014.

Interview No.3: Sanitation worker, Guangzhou, 10 August 2014.

Interview No.4: Sanitation worker, Guangzhou, 14 August 2014.

Interview No.5: Sanitation worker, Guangzhou, 15 August 2014.

Interview No.6: Sanitation worker, Guangzhou, 19 August 2014.

Interview No.7: Sanitation worker, Guangzhou, 19 August 2014.

Interview No.8: HKCTU officer, Hong Kong SAR, 25 October 2014.

Interview No.8: Labour NGO officer, Hong Kong SAR, 26 October 2014.

Interview No.9: Labour activist and former worker, Hong Kong SAR, 24 October 2014.

Interview No.10: Academic, Capital University of Economics and Business, 16 December 2014.

Interview No.11: Labour Lawyer, London, 14 September 2014.

\section{References}

Borrus, M., Ernst, D., \& Haggard, S. (ed.). (2000). International Production Networks in Asia: Rivalry or Riches? Abingdon: Routledge.

Andrew, A. (1983). Class in itself and Class Against Capital: Karl Marx and his Classifiers. Canadian Journal of Political Science 16(3) 577-584.

Butollo, F. (2014). The End of Cheap Labour: Industrial Transformation and "Social Upgrading” in China, Frankfurt-on-Main: Campus.

Case Study Reports (2007). Establishing a trade union for port workers. http://web.warwick.ac.uk/russia/ngpa/cases.htm.

Chan, A. (1998). China's Workers Under Assault: The Exploitation of Labor in a Global Economy, London: M.E. Sharpe. 
Chan, C. (2009). Strike and changing workplace relations in a Chinese global factory. Industrial Relations Journal 40(1), 60-77.

Chan, C. and Hui, E. (2012). The Dynamics and Dilemma of Workplace Trade Union Reform in China. Journal of Industrial Relations, 54(5), 653-668.

Chan, C. and Hui, E. (2017). Bringing Class Struggles Back: A Marxian analysis of the state and class relations in China. Globalizations

Chan, C. and Pun Ngai (2009). The Making of a New Working Class? A study of Collective Actions of Migrant Workers in South China. China Quarterly, 198 287-303.

Chen Weiguang (2013). Reform of the Trade Union System, towards wage consensus and sustainability between labour and capital: Investigation into the current situation of wage collective consultation in the Guangzhou auto sector (gaige he wanshan gonghui gongzuo tixi zujin gongzi laozi gongjue zhi ke chixu fazhan. Guangzhou qiche zhizao ye gongzi jiti xieshang xianzhuan de diaocha) Unpublished - on file with author.

China Labour Bulletin (2001). Reform or Revolution: Discussions between Chinese workers and Han Dongfang, Hong Kong: China Labour Bulletin.

China Labour Bulletin (2014). Searching for the Union. http://www.clb.org.hk/en/researchreports.

China Labour Bulletin (2014a). More than ten thousand workers stage massive strike at Dongguan shoe factory. http://www.clb.org.hk/en/content/more-ten-thousand-workersstage-strike-massive-dongguan-shoe-factory.

China Labour Bulletin (2014b). Striking sanitation workers seek new model of collective bargaining. http://www.clb.org.hk/en/content/striking-sanitation-workers-seek-newmodel-collective-bargaining.

China Labour Bulletin (2014c). Unity is strength: the story of Guangzhou University Town sanitation workers' strike. http://www.clb.org.hk/en/content/unity-strength-storyguangzhou-university-town-sanitation-workers $\%$ E2\%80\%99-strike.

China Labour Bulletin (2015). http://strikemap.clb.org.hk/strikes/en

Clarke, S. (2014). Sojourn: Journal of Social Issues in South East Asia, 29 (3), 758-760.

Cohen, G. (1980) Karl Marx's Theory of History: A Defence, Oxford: Clarendon Press.

Cole, N. and Chan, J. (2015). Despite claims of progress, labor and environmental violations continue to plague Apple, Open Democracy, https://www.opendemocracy.net/beyondslavery/nicki-lisa-cole-jenny-chan/despiteclaims-of-progress-labor-and-environmental-violatio.

Friedman. E. (2013). Insurgency and Institutionalization: the Polyanian countermovement and Chinese politics. Theory and Society, 42, pp.295-327.

Friedman, E. (2012). China in Revolt. Jacobin 7-8, https://www.jacobinmag.com/2012/08/china-in-revolt/.

$\mathrm{Fu}, \mathrm{D}$. (2009). A cage of voices: Producing and Doing Dagongmei in Contemporary China. Modern China, 35(5), 527-561.

GDFTU News Centre

http://www.gdftu.org.cn/xwdt/ttxw/201407/t20140715_498842.htm.

Gong Ping She (2014). In conversation with a Yue Yuen veteran (yu Yue Yuen yi wei lao gongren de shendu fangtan). http://blog.sina.com.cn/s/blog ed2baf420101wdoo.html.

$\begin{array}{lllll}\text { International } & \text { Workingmen's } & \text { Association } & 1867 & \text { (2015). }\end{array}$ https://www.marxists.org/archive/marx/iwma/documents/1867/rules.htm

Koo, H. (2001). Korean Workers: The culture and politics of class formation. Ithaca \& London: Cornell University Press.

Lee, C.K. (2007). Against the Law: Labor Protests in China's Rustbelt and Sunbelt, Berkeley: University of California Press. 
Libcom.org (2014). New Foundations for Struggle and Solidarity: The culmination of development and privatization on a Guangzhou Island. http://libcom.org/blog/guangzhou-sanitation-strike.

Liu, M. (2010). Union Organizing in China: Still a Monolithic Labor Movement? ILR Review, 64(1), 30-52.

Lyddon, D., Cao, X., Meng, Q. and Lu, J. (2015), A strike of "unorganised" workers in a Chinese car factory: the Nanhai Honda events of 2010. Industrial Relations Journal 46(2), 134-152.

Marx, K. and Engels, F. (176). Collected Works Vol. 11, New York: International Publishers.

Mitchell, T. (2009). China's Migrant Workers Face Bleak Outlook, Financial Times, 9 February.

Pringle, T. (2013). Reflections on Labor in China: From a moment to a movement. South Atlantic Quarterly, 112(1), 191-202.

Pringle, T. and M. Quan (forthcoming) 'From structural power to 'appropriated associational power' - class struggle and collective bargaining on a Chinese waterfront', ILR Review.

Pun Ngai and Lu Huilin (2010). Unfinished proletarianisation: Self, Anger and Class Action among the Second Generation of Peasant-Workers in Present-Day China. Modern China, $35(6), 493-519$.

Schmitt, B. (2013). Honda workers on strike in China, the truth about cars, http://www.thetruthaboutcars.com/2013/03/honda-workers-on-strike-in-china/.

Schmalz, S., Sommer B, and Hui Xu (2017) The Yue Yuen Strike: Industrial Transformation and Labour Unrest in the Pearl River Delta. Globalizations.

Smith, C. and Chan, J. (2015). Working for two bosses: Student interns as constrained labour in China, Human Relations, 68(2), 305-326.

Thompson, E.P. (1963). The Making of the English Working Class. Toronto: Penguin Books.

Wright, E.O. (2000). Working-Class Power, Capitalist-Class Interests, and Class Compromise, 105(4), 957-1002.

Yu Xiaomin and Pun Ngai (2011). Walmartization, Corporate Social Responsibility, and the Labor Standards of Toy Factories in China in Walmart in China, Anita Chan (ed.), (pp 54-70). Ithaca: ILR Press. 